\title{
Factors Affecting Dysmenorrhea in Junior High School Students X South Jakarta
}

\author{
Fembriya Tenny Utami \\ Faculty of Public Health, Muhammadiyah University of Jakarta \\ K.H. Ahmad Dahlan St, Cireundeu, Ciputat, South Jakarta, Banten 15419 \\ E-mail: ftu.ftu10@gmail.com
}

\begin{abstract}
One of the menstrual disorders that cause physical discomfort is dysmenorrhea. Dysmenorrhea is menstrual pain that is felt in the lower abdomen and radiates to the pelvis which can interfere with daily activities. The magnitude of the prevalence rate of the incidence of dysmenorrhea, which reaches $90 \%$, and can affect the activities of adolescents during menstruation, so it is necessary to look at the factors associated with the incidence of dysmenorrhea. The purpose of this study was to determine the factors associated with the incidence of dysmenorrhea in junior high school students. The type of research used is observational with a cross-sectional study approach using a questionnaire instrument. The population is all students of SMP 212 South Jakarta. The population of 103 students was obtained by proportional random sampling. The statistical test used was Chi-square with $p=0.05$. The results showed the relationship between dysmenorrhea and menarche, length of menstruation, and exercise $p>0.05$. The results of the statistical analysis test showed that the dependent variables such as age at menarche, duration of menstruation, and lack of exercise were not associated with the incidence of dysmenorrhea because they had a value of $\hat{I} \pm>0.05$. The conclusion of this study is that age at menarche, duration of menstruation, and lack of exercise do not affect the occurrence of dysmenorrhea.
\end{abstract}

Keywords: Dysmenorrhea, Menstruation, Exercise, Adult 


\section{INTRODUCTION}

Every month, women aged 12-49 years, not pregnant yet menopausal generally experience menstruation or menstruation. Menstruation is the event of bleeding from the vagina. This blood comes from the uterine cavity and arises due to the release of the mucous membrane of the uterus (endometrium) which undergoes a process of decline and damage (desquamation). Therefore, in addition to normal menstrual blood, there are remnants and debris from the mucous membrane of the uterus. The length of a normal menstrual cycle is 28 days, but 26-30 days is still considered normal, with the length of one menstrual period ranging from 3-7 days. The cycle is influenced by the ovarian hormones, namely estrogen, and progesterone. During menstruation, the problem that many women experience is severe discomfort or pain. This is commonly called dysmenorrhea.

Dysmenorrhea is a complaint that usually starts one week to a few days before the arrival of menstruation and disappears after menstruation comes although sometimes it continues until menstruation stops. Dysmenorrhea causes lower abdominal pain, which can radiate to the lower back and legs. Pain is felt as intermittent cramping or as a persistent dull ache. In addition to pain, dysmenorrhea is also often accompanied by headaches, nausea, constipation or diarrhea, and frequent urination, sometimes vomiting occurs.

Dysmenorrhea is menstrual pain that is so severe that it forces the sufferer to rest and leave work or daily life for several hours or days. Usually, patients self-medicate with analgesics or see a doctor. The pathophysiology of dysmenorrhea is still unclear, but recently the prostaglandin theory is widely used, it is said that in the state of dysmenorrhea, prostaglandin levels increase.

Dysmenorrhea is divided into two, namely primary dysmenorrhea and secondary dysmenorrhea. Of the two dysmenorrhea, primary dysmenorrhea is the most common in the community.

Primary dysmenorrhea is a feeling of heartburn, pain in the lower abdomen and is felt during menstruation, which is mostly experienced in adolescence without any pathological complaints such as endometriosis. While secondary dysmenorrhea was found mostly at reproductive age.

Most people with dysmenorrhea are teenagers and young women, although it is also found among the elderly. The most common dysmenorrhea is primary dysmenorrhea, more than $50 \%$ of women may experience it and 10-15\% of them experience severe pain that interferes with women's daily activities and activities. Primary dysmenorrhea usually occurs in adolescence, which is about 23 years after the first menstruation and occurs at the age of fewer than 20 years.

Adolescence is a phase of growth and development between childhood and adulthood. According to the 1998 Youth Manifesto, the age limit for youth is 10-24 years. The number of adolescents (10-24 years) is currently around 30\% of the total population of Indonesia. 


\section{METHODS}

This research is quantitative with a cross-sectional research design. The author researched variables taken at the same time. A cross-sectional study is one type of observational study to determine the relationship between the independent variable and the dependent variable. This research will be conducted at SMP 212, South Jakarta. The population in this study were all female students at SMP 212, South Jakarta. The total population is 306 people.

\section{RESULTS AND DISCUSSIONS}

Table 1. Distribution of Menarche, Menstruation Length, and Sport

\begin{tabular}{llcc}
\hline \multicolumn{1}{c}{ Distribution } & & Number of people & $(\boldsymbol{\%})$ \\
\hline \multirow{2}{*}{ Menarche } & $<12$ years old & 61 & 59.2 \\
& 12 years & 42 & 40.8 \\
Menstruation Length & 7 days & 63 & 61.2 \\
& $>7$ days & 40 & 38.8 \\
Sport & Yes & 38 & 36.9 \\
& Not & 65 & 63.1 \\
\hline
\end{tabular}

Table 2. Relationship between Menarce and Dysmenorrhea

\begin{tabular}{|c|c|c|c|c|c|}
\hline \multirow{3}{*}{ Menarche } & \multirow[b]{3}{*}{$<12$ years old } & \multirow{4}{*}{$\begin{array}{l}\text { Number of people } \\
\%\end{array}$} & \multicolumn{2}{|c|}{ Dysmenorrhea } & \multirow{2}{*}{ Total } \\
\hline & & & Yes & No & \\
\hline & & & 48 & 13 & 61 \\
\hline & & & $78.7 \%$ & $21.3 \%$ & $100.0 \%$ \\
\hline & +- 12 years & Number of people & 26 & 16 & 42 \\
\hline & & $\%$ & $61.9 \%$ & $38.1 \%$ & $100.0 \%$ \\
\hline \multirow[t]{2}{*}{ Total } & & Number of people & 74 & 29 & 103 \\
\hline & & $\%$ & $71.8 \%$ & $28.2 \%$ & $100.0 \%$ \\
\hline
\end{tabular}

From the results of the bivariate test, the $\mathrm{p}$-value $=0.143$, so there was no significant relationship between the length of menstruation and dysmenorrhea. It is possible that this happened because respondents who experienced menstrual periods of more than 7 days and normal ones were equally dominant in experiencing dysmenorrhea. It is also possible that there is no relationship between the length of menstruation and dysmenorrhea related to the physiological condition of the respondents.

Table 3. Relationship between Exercise and Dysmenorrhea

\begin{tabular}{|c|c|c|c|c|c|}
\hline & & & \multicolumn{2}{|c|}{ Dysmenorrhea } & \multirow{2}{*}{ Total } \\
\hline & & & Yes & $\mathrm{Nc}$ & \\
\hline \multirow{4}{*}{ Sport } & \multirow{2}{*}{ Yes } & Number of people) & 26 & 12 & 38 \\
\hline & & $\%$ & $68.4 \%$ & $31.6 \%$ & $100.0 \%$ \\
\hline & \multirow{2}{*}{ No } & Number of people) & 48 & 17 & 65 \\
\hline & & $\%$ & $73.8 \%$ & $26.2 \%$ & $100.0 \%$ \\
\hline \multirow{2}{*}{ Total } & & Number of people) & 74 & 29 & 103 \\
\hline & & $\%$ & $71.8 \%$ & $28.2 \%$ & $100.0 \%$ \\
\hline
\end{tabular}


From the results of the bivariate test, $\mathrm{p}$-value $=0.555$, so there is no significant relationship between exercise and dysmenorrhea. From previous research, it is said that there is a relationship between exercise and dysmenorrhea. The possibility that there is no relationship in this study is because many respondents who do sports with those who do not exercise still experience dysmenorrhea.

\section{CONCLUSIONS AND SUGGESTIONS}

From the research that has been done, it can be concluded that there is no significant relationship between menarche and dysmenorrhea, length of menstruation and dysmenorrhea, and exercise with dysmenorrhea.

The results of this study are only local, that is, certain of the population used as research subjects (students of SMP 212 Jakarta), so it is necessary to do further research with a wider population to get a broader picture at the student population level in Jakarta or Indonesia. The researcher also suggests that in further research the number of samples can be added. It is also hoped that further research can be carried out in other cities or regions.

\section{REFERENCES}

Andi Nurul Rifqah Utami, Jumriani Ansar, Dian Sidik. FACTORS RELATED TO THE EVENT OF DYMENOROREA IN ADOLESCENT WOMEN AT SMAN 1 KAHU, BONE REGENCY. 2012. Available from

URL:http://repository.unhas.ac.id/bitstream/handle/123456789/5523/jurnal.pdf?sequence=1.

Anurogo, dito., Ari Wulandari. 2011. The Right Way to Overcome Menstrual Pain. Andi Publisher: Yogyakarta

Desni Roza. Characteristics of Dysmenorrhea Symptoms and Their Influence on Learning Activities of Undergraduate Nursing Students in Extension Class at the USU Faculty of Nursing. 2011. Available from URL:http://repository.usu.ac.id/bitstream/123456789/24617/7/Cover.pdf

Frenita Sophia. FACTORS RELATED TO DYMENORRHEA IN STUDENTS OF SMK NEGERI 10 MEDAN IN 2013. Available from URL :http://jurnal.usu.ac.id/index.php/gkre/article/download/4060/1894.

Mohamed, Eman M. 2012. Epidemiology among adolescent students in Assiut City, Egypt. Life Science Journal 9 (1). 348-353

Novia I. Risk Factors Affecting the Incidence of Primary Dysmenorrhea (Study in Banjar Kemantren Village, Buduran District, Sidoarjo Regency). [Thesis]. Airlangga University. Surabaya; 2009. 